\title{
Protective effect of Pterostilbene against free radical mediated oxidative damage
}

\author{
Jhankar D Acharya and Saroj S Ghaskadbi
}

\begin{abstract}
Background: Pterostilbene, a methoxylated analog of Resveratrol, is gradually gaining more importance as a therapeutic drug owing to its higher lipophilicity, bioavailability and biological activity than Resveratrol. This study was undertaken to characterize its ability to scavenge free radicals such as superoxide, hydroxyl and hydrogen peroxide and to protect bio-molecules within a cell against oxidative insult.

Methods: Anti-oxidant activity of Pterostilbene was evaluated extensively by employing several in vitro radical scavenging/inhibiting assays and pulse radiolysis study. In addition, its ability to protect rat liver mitochondria against tertiary-butyl hydroperoxide (TBHP) and hydroxyl radical generated oxidative damage was determined by measuring the damage markers such as protein carbonyls, protein sulphydryls, lipid hydroperoxides, lipid peroxides and 8-hydroxy-2'-deoxyguanosine. Pterostilbene was also evaluated for its ability to inhibit $\bullet \mathrm{OH}$ radical induced single strand breaks in pBR322 DNA.

Result: Pterostilbene exhibited strong anti-oxidant activity against various free radicals such as DPPH, ABTS, hydroxyl, superoxide and hydrogen peroxide in a concentration dependent manner. Pterostilbene conferred protection to proteins, lipids and DNA in isolated mitochondrial fractions against TBHP and hydroxyl radical induced oxidative damage. It also protected pBR322 DNA against oxidative assault.
\end{abstract}

Conclusions: Thus, present study provides an evidence for the strong anti-oxidant property of Pterostilbene, methoxylated analog of Resveratrol, thereby potentiating its role as an anti-oxidant.

Keywords: Anti-oxidant activity, Free radicals, Oxidative stress, Pterostilbene

\section{Background}

Several polyphenols are well-known in inducing an array of biological responses in animal cells such as modulation of intercellular signaling, altered gene expression, protection against oxidation and enzyme inhibition. Among different classes of polyphenols, Stilbenoids, low molecular weight phenolics, are present in a very small proportion, and have not been studied to a great extent until recently. Resveratrol was first such stilbene to be found and isolated, and has been studied extensively since then for various activities such as anti-cancer, antioxidant, anti-inflammatory and several other beneficial activity [1].

Pterostilbene (trans-3,5-dimethoxy-4'-hydroxystilbene) is another such stilbene which is a naturally occurring methoxylated analog of Resveratrol and owing to its

\footnotetext{
*Correspondence: ssg@unipune.ac.in

Department of Zoology, University of Pune, 411007 Pune, India
}

close structural similarity with Resveratrol, has gained importance [2]. Replacement of two hydroxyl groups with methoxy groups increases its oral bio-availability, and biological activity and slows its metabolism thereby prolonging its activity. It has been reported to be identified from various plant sources like the heartwood of Pterocarpus santalinus [3], Pterocarpus marsupium [4], leaves of Vitis Vinifera [5] and in healthy and immature berries of Pinot Noir and Gamay [6]. Pterocarpus marsupium Roxb is commonly known as the Indian kino tree (known in the vernacular as "Vijaysar" of "Bijasar") and commonly grows in the central, western, and southern parts of India and in Sri Lanka. Its bark is used as an astringent, anti-diarrheal, and antacid [7] and is also effective in $\beta$-cell regeneration [8]. P. marsupium wood water has been reported to have hypoglycaemic activity in diabetic patients [9] and extract of its heartwood was found to be effective in reducing plasma glucose levels
C Biomed Central

(c) 2013 Acharya and Ghaskadbi; licensee BioMed Central Ltd. This is an Open Access article distributed under the terms of the Creative Commons Attribution License (http://creativecommons.org/licenses/by/2.0), which permits unrestricted use, distribution, and reproduction in any medium, provided the original work is properly cited. 
in newly-diagnosed diabetic patients [10]. Darakchasava, an ayurvedic medicine, is a well-known Indian herbal preparation of Vitis Vinifera and has been cited to have Pterostilbene as a major phenolic compound in it at a concentration of $6.8 \mathrm{mg} / \mathrm{l}$ whereas Resveratrol was present at a concentration of $1.3 \mathrm{mg} / \mathrm{l}$ [11]. Pterostilbene is attributed to have anti-diabetic [12-14], anti-cancer, anti-inflammatory [15-18] and anti-obesity [19] activity and is known to have anti-oxidant activity $[2,20]$ comparable to Resveratrol [21]. Although anti-oxidant activity of Pterostilbene has been reported in terms of its ability to scavenge DPPH, ABTS and peroxyl radical, there exist scanty evidences in support of this view, and detailed analysis of its anti-oxidant activity needs to be evaluated.

Therefore, the present study was undertaken to characterize the free radical scavenging/inhibiting activity of Pterostilbene against an array of free radicals generated in vitro. In addition to this, its ability to confer protection to bio-molecules (lipids, proteins and DNA) from oxidative damage was also checked.

\section{Methods}

\section{Chemicals and biologicals}

2,2' - azobis-3-ethylbenzthiazoline-6-sulfonic acid (ABTS) diammonium salt, 1,1'-diphenyl-2- picrylhydrazyl (DPPH), ferric chloride, myoglobin, potassium ferricyanide, and 2-thiobarbituric acid (TBA) were purchased from Sigma Chemical Co., USA. All other chemicals used were purchased from Sisco Research Laboratories, India, HiMEDIA, India or Merck, Germany. Pterostilbene was purchased from Sigma, USA.

Pulse radiolysis study was done using linear accelerator (LINAC) electron pulse radiolysis system at the National Center for Free Radical Research, Pune University Campus, Pune, India.

Three months old male or female Wistar rats weighing $250 \pm 20 \mathrm{~g}$ were used to isolate rat liver mitochondria and were procured from animal house facility of Institute of Veterinary and Biological Sciences, Pune. They were housed in polypropylene cages maintained at $25 \pm$ $2^{\circ} \mathrm{C}$ with 12:12 h light and dark cycle. They were given feed and water ad libitum. Prior approval was obtained from the Pune University Institutional Animal Ethical Committee for the protocols used involving animals (Registration no. 538/02/c/CPCSEA).

\section{Methods}

A. In vitro radical scavenging assays

Different concentrations of Pterostilbene (0.05, 0.10, 0.15 and $0.20 \mathrm{mM}$ ) were used for different radical scavenging/inhibiting assays. L-ascorbic acid was used as a standard and the activity of Pterostilbene was expressed as ascorbic acid equivalent antioxidant capacity (AEAC). DPPH radical scavenging activity was carried out according to the method of Aquino et al. [22]. In this method, DPPH•, a stable free radical having an absorption maximum at $515 \mathrm{~nm}$ was used which disappears on reduction in the presence of an anti-oxidant. The ferric reducing ability of Pterostilbene was measured using ferric reducing ability of plasma assay (FRAP) assay [23]. In this method ferric to ferrous ion reduction at low $\mathrm{pH}$ led to the formation of ferrous-tripyridyltriazine complex which was measured at $593 \mathrm{~nm}$. Total antioxidant capacity (TAC) was estimated using the ferrylmyoglobin/ABTS method [24] which quantitates the relative ability of anti-oxidants to scavenge the 2,2'-azinobis(3-ethylbenzothiazoline-6sulfonate) radical cation $\left(\mathrm{ABTS}^{+}\right)$. Hydroxyl radical scavenging activity was assayed according to the method of Halliwell et al. [25] by deoxyribose degradation method. $\mathrm{H}_{2} \mathrm{O}_{2}$ scavenging assay was performed according to the method of Nabavi et al. [26]. In this assay decrease in $\mathrm{H}_{2} \mathrm{O}_{2}$ concentration in the presence of different concentrations of Pterostilbene was measured at $240 \mathrm{~nm}$. Superoxide radical scavenging activity was assayed spectrophtometrically by xanthine/xanthine oxidase according to Ukeda et al. [27] where the extent to which Pterostilbene inhibits the reduction of nitroblue-tetrazolium (NBT) by superoxide radical was monitored at $560 \mathrm{~nm}$ and expressed as \% radical inhibition.

A.1. Pulse radiolysis

The ability of the Pterostilbene to scavenge $\mathrm{ABTS}^{+}, \mathrm{CO}_{3}{ }^{-}$and $\bullet \mathrm{OH}$ radicals was determined by pulse radiolysis. ABTS $^{+}$radical was produced by reacting radiolytically generated azide radicals with ABTS. $\mathrm{CO}_{3}{ }^{-}$ radicals were generated using a reaction mixture containing $\mathrm{NaHCO}_{3}$ and $\mathrm{Na}_{2} \mathrm{CO}_{3}$ saturated with nitrous oxide $\left(\mathrm{N}_{2} \mathrm{O}\right)$. In the presence of Pterostilbene, the decay of $\mathrm{ABTS}^{+}$ and $\mathrm{CO}_{3}{ }^{-}$were monitored and correlated with the concentration of ascorbic acid equivalents [28].

Scavenging of $\bullet \mathrm{OH}$ was determined by competition kinetic methods. Irradiation of water with $7 \mathrm{MeV}$ electron pulse (50 ns pulse width) and dose rate of 17 Gy/pulse generates hydroxyl radicals, hydrated electrons and hydrogen atoms. To measure only the reactions of the $\cdot \mathrm{OH}$, all solutions were pre-saturated with $\mathrm{N}_{2} \mathrm{O}$ to remove dissolved oxygen gas and to quantitatively convert the hydrated electrons and hydrogen atoms to $\bullet \mathrm{OH}$. The ability of 
Pterostilbene to scavenge hydroxyl radicals was analysed by competition kinetics using potassium thiocyanate (KSCN) as a standard. In this method, $\bullet \mathrm{OH}$ is made to react with $\mathrm{KSCN}$ in the absence and/or in the presence of different concentrations of Pterostilbene. $\cdot \mathrm{OH}$ reacts competitively with $\mathrm{SCN}$ to produce $(\mathrm{SCN})_{2} \cdot-$ which absorbs at $480 \mathrm{~nm}$. In the presence of different concentrations of Pterostilbene, decrease in the formation of $(\mathrm{SCN})_{2} \bullet$ - was measured. The difference between rate constant of $(\mathrm{SCN})_{2} \cdot-$ in presence and absence of Pterostilbene was calculated $[29,30]$. The rate of hydroxyl radical scavenging was the slope of linear plot of this difference versus concentration of Pterostilbene.

B. Isolation of rat liver mitochondria and exposure to oxidative stress

Three-months old female Wistar rats were used for the preparation of mitochondria as described previously [31]. Briefly, rat liver was excised, and homogenized in $0.25 \mathrm{M}$ sucrose containing $1 \mathrm{mM}$ EDTA. The homogenate was centrifuged at $3000 \mathrm{~g}$ for 10 mins to remove cell debris and the nuclear fraction. The resultant supernatant was centrifuged at $10,000 \mathrm{~g}$ for 10 mins to sediment mitochondria. This pellet was washed with $5 \mathrm{mM}$ phosphate buffer, $\mathrm{pH}$ 7.4. Protein was estimated by the method of Lowry et al. [32] and pellet was suspended in the sucrose-EDTA buffer.

Isolated mitochondria were exposed to oxidative damage induced by tertiary butyl hydroperoxide (TBHP) and ascorbic acid and iron containing system $\left(\mathrm{As}^{-} \mathrm{Fe}^{2+}\right)$ [33]. Briefly, mitochondria corresponding to $500 \mu \mathrm{g}$ of protein were incubated with $400 \mu \mathrm{M}$ TBHP and As- $\mathrm{Fe}^{2+}$ in the presence or absence of different concentrations of Pterostilbene for $60 \mathrm{mins}$ at $37^{\circ} \mathrm{C}$. The treated mitochondria were checked for oxidative damage caused to lipids, proteins and DNA.

\section{B.1. Oxidative damage to Proteins}

Protein carbonyls were quantitated based on the reaction of carbonyl groups with 2,4dinitrophenylhydrazine (DNPH) to form a 2,4dinitrophenylhydrazone, which can be measured at $365 \mathrm{~nm}$ [34]. The difference in the absorbance between blank and corresponding experiment gives the amount of carbonyl formed and was expressed as nmoles of protein carbonyls formed per milligram protein.

Protein sulphydryls were quantitated using Ellman's reagent (5,5-dithiobis-2-nitrobenzoic acid) and expressed as nmoles protein sulphydryls per mg protein [35].

\section{B.2. Oxidative damage to lipids}

TBARs were quantitated following the protocol of Devasagayam et al. [31] with slight modifications.

Mitochondrial fractions after induction of oxidative damage were made to react with TBA reagent, boiled for 1 hour and the pink color developed due to TBARs formed was quantitated at $532 \mathrm{~nm}$ spectrophotometrically and expressed as nmoles of malondialdehyde (MDA) equivalents formed $/ \mathrm{ml}$ after accounting for appropriate blanks.

Lipid hydroperoxides were estimated using FOXII reagent following the protocol of Nourooz-Zadeh et al. [36]. The working FOXII reagent was calibrated against known concentrations of hydrogen peroxide. Samples were made to react with FOXII reagent and incubated for 45 mins at $37^{\circ} \mathrm{C}$, spun and absorbance was read at $560 \mathrm{~nm}$.

\section{B.3. Oxidative damage to DNA}

Estimation of 8-hydroxy-2'-deoxyguanosine (8-OHdG)

Mitochondrial DNA was isolated using Nucleospin Tissue kit (Macherey-Nagel, USA) and quantitated on a nanophotometer. 8-OHdG concentration in DNA was determined by competitive ELISA using monoclonal antibody against 8-OHdG following the protocol of Modak et al. [37] and expressed as ng of 8-OHdG per 100 ng DNA.

C. Inhibition of single strand breaks in pBR322 plasmid DNA against oxidative damage pBR322 DNA was exposed to $\bullet \mathrm{OH}$ radicals generated by the addition of hydrogen peroxide and ferrous sulphate in the presence and/or absence of different concentrations of Pterostilbene. Single strands generated in plasmid DNA were measured by quantitating the conversion of supercoiled DNA to nicked circular form, according to the procedure described by Zhao et al. [38]. Following incubation, the samples were immediately loaded onto $1 \%$ agarose gels and electrophoresed. The gel was stained with ethidium bromide and the fluorescence was observed under UV and the intensity of the bands was measured using Gel Documentation System (Alpha Innotech Corporation, USA).

\section{Statistical analysis}

All the experiments were repeated four times and the data represents average of these sets with standard error. 
One-way analysis of variance (ANOVA) followed by post-hoc test was performed to determine the statistical significance of the differences among different experimental groups using SPSS 17.0 software. P value less than 0.05 was considered statistically significant and was indicated by dissimilar alphabets a, b, c, d and e in superscript.

\section{Results}

\section{High anti-oxidant activity of Pterostilbene}

The anti-oxidant activity of Pterostilbene was estimated by performing several biochemical assays which determine either its free radical scavenging activity or its ability to inhibit formation of free radicals at different concentrations
(0.05, 0.1, 0.15 and $0.2 \mathrm{mM})$. In DPPH radical scavenging assay, Pterostilbene exhibited concentration dependent activity from $0.05 \mathrm{mM}$ to $0.15 \mathrm{mM}$ Pterostilbene, with no further increase at $0.2 \mathrm{mM}$ (Figure 1A). Pterostilbene also exhibited ability to reduce ferric to ferrous in a concentration dependent manner as assayed by FRAP assay (Figure 1B) with a maximum value of $27.5 \pm 3.62 \mathrm{mM}$ $\mathrm{AEAC}$ at $0.2 \mathrm{mM}$ concentration. Figure $1 \mathrm{C}$ shows ability of Pterostilbene to inhibit ABTS radical formation which was assayed using ferrylmyoglobin $/ \mathrm{ABTS}^{+}$detection method. Pterostilbene demonstrated concentration dependent inhibition of ABTS radical formation with a maximum value of $0.11 \pm 0.001 \mathrm{mM} \mathrm{AEAC}$ at $0.2 \mathrm{mM}$ concentration of Pterostilbene.

\section{A. DPPH}

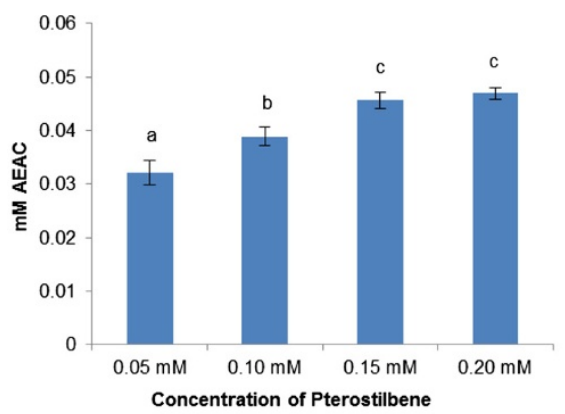

C. ABTS

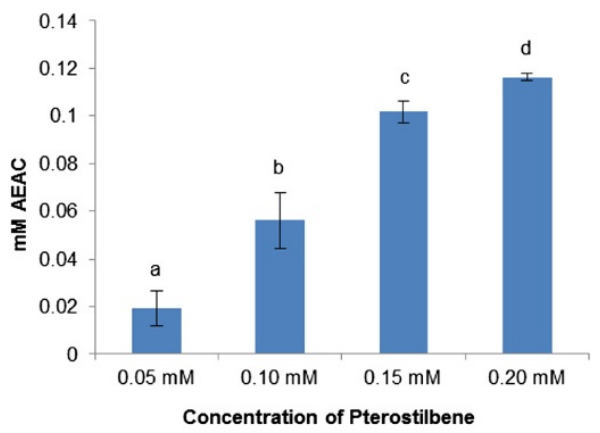

E. Superoxide radical

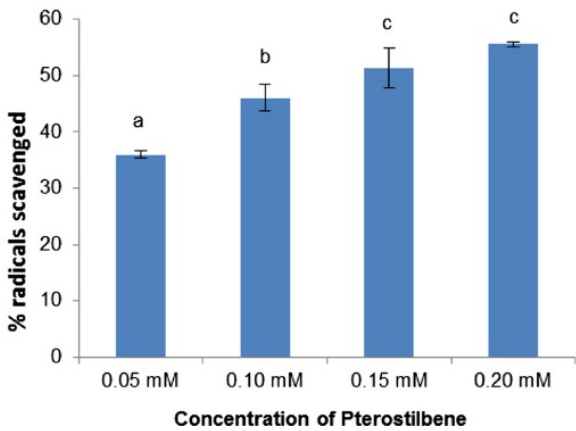

\section{B. FRAP Assay}

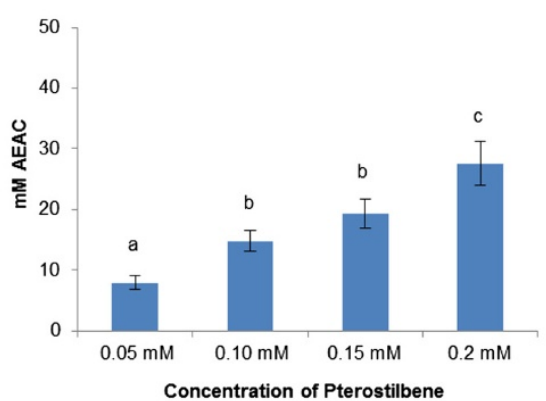

\section{Hydroxyl radical}

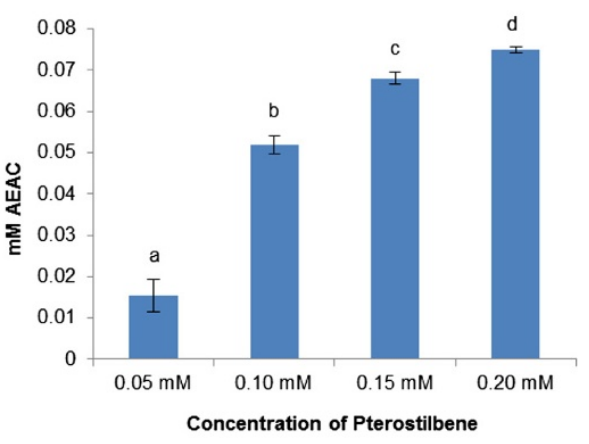

F. $\mathrm{H}_{2} \mathrm{O}_{2}$ assay

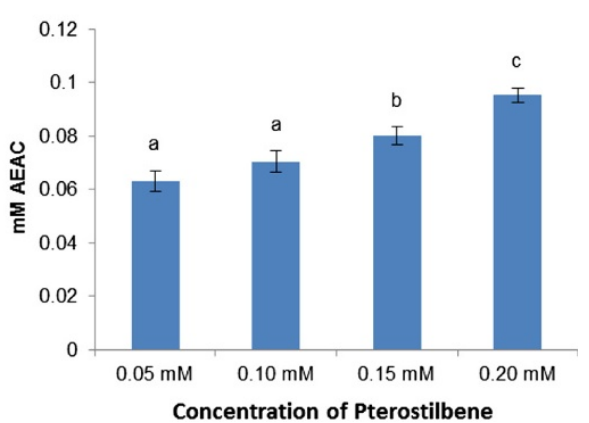

Figure 1 Radical scavenging/inhibition by Pterostilbene. (A) DPPH, (B) FRAP Assay, (C) ABTS, (D) Hydroxyl radical, (E) Superoxide radical and (F) $\mathrm{H}_{2} \mathrm{O}_{2}$ assay. 
Superoxide radical scavenging activity of Pterostilbene was estimated by nitroblue tetrazolium reduction by xanthine-xanthine oxidase method. At the maximum concentration used Pterostilbene resulted in reduction of superoxide radicals by $55.6 \pm 0.5 \%$ (Figure $1 \mathrm{E}$ ). Similarly, Pterostilbene also exhibited concentration dependent increase in its ability to scavenge hydroxyl radical and hydrogen peroxide (Figure $1 \mathrm{D}$ and $1 \mathrm{~F}$ ) with maximum ability of $0.09 \pm 0.001 \mathrm{mM} \mathrm{AEAC}$ at a concentration of $0.2 \mathrm{mM}$.

In addition to the above mentioned biochemical radical scavenging assays, Pulse radiolysis, a sensitive method to study scavenging of free radicals was employed. The linear plot of pseudo first order rate constant $\left(K_{a b s}\right)$ versus ascorbic acid concentration was used to calibrate the standard curve for different concentrations of Pterostilbene. Figure 2 shows decay curves for $\mathrm{ABTS}^{+}$and $\mathrm{CO}_{3}{ }^{-}$radicals. Pterostilbene exhibited concentration dependent increase in the ability to scavenge $\mathrm{ABTS}^{+}$and $\mathrm{CO}_{3}{ }^{-}$radical with a maximum activity at $0.2 \mathrm{mM}$ with a value of $1.38 \mathrm{mM}$ AEAC and 6.85 M AEAC, respectively (Table 1).

\section{Protection conferred against oxidatively damaged bio- molecules}

Ability of Pterostilbene to inhibit oxidative damage in isolated mitochondria was assessed by exposing them to two different oxidants: TBHP and As- $\mathrm{Fe}^{2+}$ generated hydroxyl radical in presence and or absence of Pterostilbene. Lipid

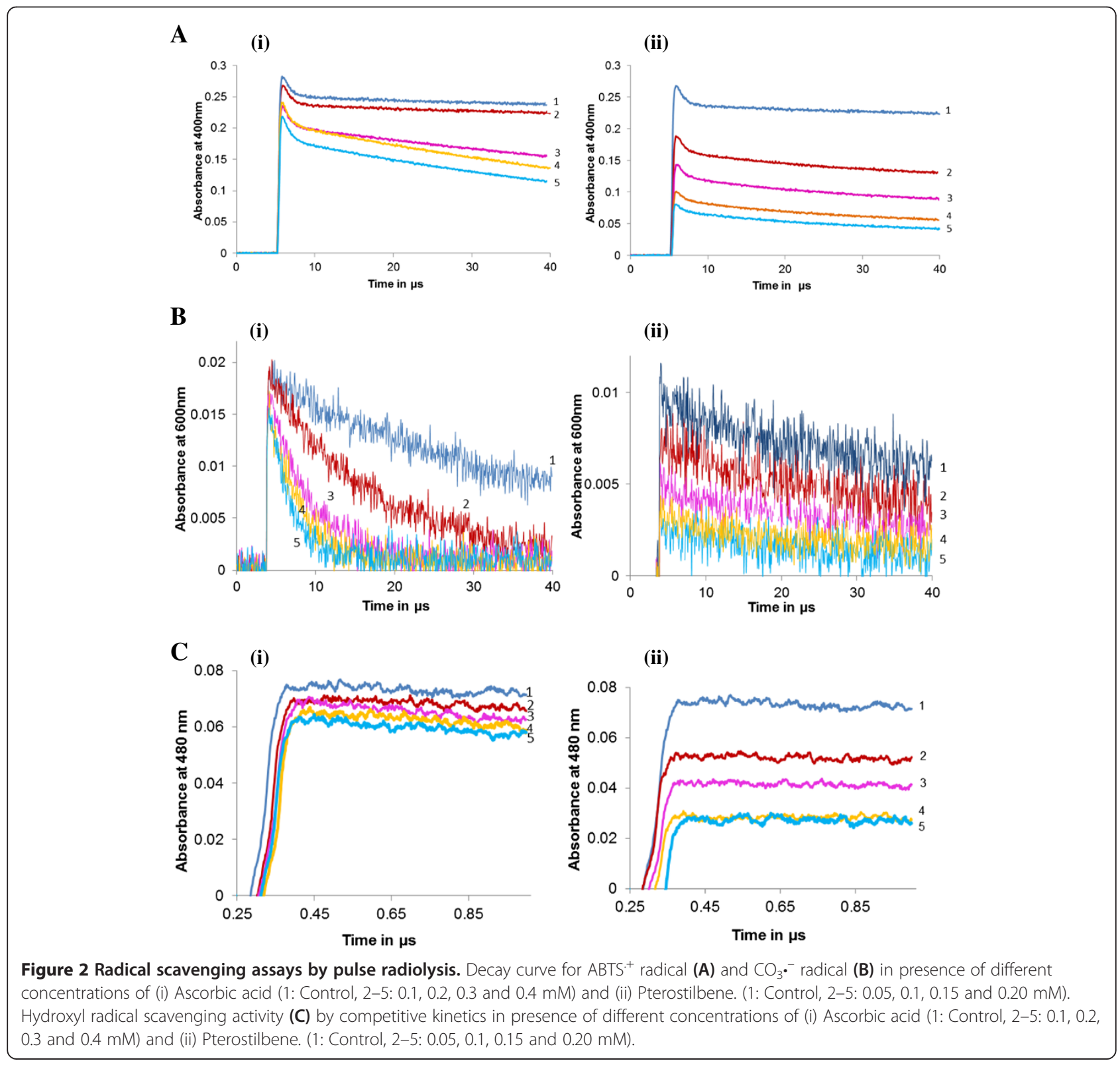


Table $1 \mathrm{ABTS}^{+}$and $\mathrm{CO}_{3} \cdot{ }^{-}$radical scavenging activity measured by pulse radiolysis for different concentrations of Pterostilbene

\begin{tabular}{lll}
\hline Pterostilbene & $\begin{array}{l}\text { ABTS } .^{+} \\
\text {mM AEAC }\end{array}$ & $\begin{array}{l}\mathrm{CO}_{3^{-}}{ }^{-} \\
\text {M AEAC }\end{array}$ \\
\hline $\mathbf{0 . 0 5} \mathbf{~ m M}$ & $1.26 \pm 0.14$ & $0.05 \pm 0.01$ \\
$\mathbf{0 . 1 0} \mathbf{~ m M}$ & $1.32 \pm 0.18$ & $1.00 \pm 0.07$ \\
$\mathbf{0 . 1 5} \mathbf{~ m M}$ & $1.38 \pm 0.11$ & $3.75 \pm 0.47$ \\
$\mathbf{0 . 2 0} \mathbf{~ m M}$ & $1.42 \pm 0.30$ & $6.85 \pm 0.87$ \\
\hline
\end{tabular}

The scavenging activity of $\mathrm{ABTS}^{+}$and $\mathrm{CO}_{3}{ }^{-}$radicals were measured in terms of ascorbic acid equivalent antioxidant capacities (AEAC)

peroxides and hydroperoxides were used as markers of oxidative damage to lipids. Pterostilbene exhibited concentration dependent reduction in the formation of lipid peroxides and hydroperoxides in response to damage by TBHP and $\mathrm{As}-\mathrm{Fe}^{2+}$. In presence of $0.2 \mathrm{mM}$ Pterostilbene the nmoles of MDA formed significantly reduced by $92.1 \pm 0.1 \%(1.11 \pm 0.00$ nmoles $\mathrm{MDA} / \mathrm{mg}$ protein $)$ and $94.1 \pm 8.1 \% \quad(0.88 \pm 0.07 \quad$ nmoles $\mathrm{MDA} / \mathrm{mg}$ protein $)$ against TBHP and $\mathrm{As}-\mathrm{Fe}^{2+}$ induced damage, respectively. Concentration of lipid hydroperoxides increased significantly after exposure to TBHP and $\mathrm{As}-\mathrm{Fe}^{2+}$ and decreased by $65.7 \pm 4.2 \%(229.6 \pm 20.1$ nmoles hydroperoxides/mg protein) and $82.5 \pm 4.6 \%(180.3 \pm 17.9$ nmoles hydroperoxides/mg protein), respectively in the presence of $0.2 \mathrm{mM}$ Pterostilbene (Table 2).

Protein carbonyl group (PCG) and protein sulphydryl group (PSG) were used as markers of oxidative damage to proteins. PCG increased significantly under oxidative stress conditions induced by TBHP and As- $\mathrm{Fe}^{2+}$, which was reduced by $99.4 \pm 0.5 \%(3.55 \pm 0.01$ nmoles protein carbonyls/mg protein) and $94.0 \pm 8.8 \%$ (3.92 \pm 0.16 nmoles protein carbonyls/mg protein), respectively, in presence of $0.2 \mathrm{mM}$ Pterostilbene. Protein sulphydryl groups reduced significantly under oxidative damage induced by TBHP and $\mathrm{As}-\mathrm{Fe}^{2+}$, which was restored to $90.2 \pm 4.8 \%(0.15 \pm$ 0.00 nmoles protein sulphydryls/mg protein) and $87.9 \pm$ $4.4 \%$ ( $1.15 \pm 0.01$ nmoles protein sulphydryls/mg protein), respectively in the presence of $0.2 \mathrm{mM}$ Pterostilbene (Table 3).

Oxidative damage to DNA results in oxidation of bases and one such modified base which is used as marker of oxidative stress is 8-hydroxy-2'-deoxyguanosine (8-OHdG). Protection conferred to mitochondrial DNA by Pterostilbene against oxidative damage was measured in terms of decrease in the formation of 8-OHdG (Table 4). Oxidative damage induced by TBHP and $\mathrm{As}-\mathrm{Fe}^{2+}$ led to an increase in the concentration of 8-OHdG which reduced significantly $(97.0 \pm 1.1 \%(0.003 \pm 4.5 \mathrm{E}-04$ nmoles of $8-O H d G / 100 \mathrm{ng}$ DNA) and $96.4 \pm 0.0 \%(0.003 \pm 7.9 \mathrm{E}-$ 04 nmoles of 8 -OHdG/100 ng DNA), respectively) in the presence of $0.2 \mathrm{mM}$ Pterostilbene $(\mathrm{p}<0.05)$.

Strong ability to inhibit single strand breaks in pBR322 Exposure to oxidative stress induces both single and double strand breaks converting the supercoiled pBR322 DNA into open circular form and linear form, respectively. Oxidative stress mediated DNA strand breaks were induced by generating $\bullet \mathrm{OH}$ radicals through Fenton reaction. Plasmid DNA was exposed to $\mathrm{OH}$ radicals and was significantly damaged as seen in lane 2 (Figure 3A) where $66.2 \pm$ $0.4 \%$ DNA was converted to nicked circular form compared to the untreated pBR322 in lane 1 where $68.9 \pm 7.1 \%$ DNA remained in supercoiled form. Densitogram analysis (Figure 3B) revealed that in the presence of Pterostilbene alone, $70.1 \pm 2.3 \%$ DNA remained in supercoiled form (lane 3) $(p<0.05)$. Pterostilbene inhibited the formation of single strand breaks after exposure to $\cdot \mathrm{OH}$ radicals in a concentration dependent manner (Lanes 4-7).

\section{Discussion}

Extract of Pterocarpus marsupium, an Indian medicinal plant, has been demonstrated to have anti-oxidant

Table 2 Inhibition of lipid oxidation by PTS was measured in terms of nmoles MDA/mg protein and $\mathbf{n m o l e s}$ of hydroperoxides/mg protein in TBHP and $\mathrm{As}-\mathrm{Fe}^{2+}$ mediated oxidatively damaged rat liver mitochondria

\begin{tabular}{|c|c|c|c|c|}
\hline & \multicolumn{2}{|c|}{ Lipid peroxides } & \multicolumn{2}{|c|}{ Lipid hydroperoxides } \\
\hline & \multicolumn{2}{|c|}{ (nmoles MDA/mg protein) } & \multicolumn{2}{|c|}{ (nmoles hydroperoxides/mg protein) } \\
\hline & TBHP & As- $-\mathrm{Fe}^{2+}$ & TBHP & $\mathrm{As}-\mathrm{Fe}^{2+}$ \\
\hline Control & $0.95 \pm 0.01^{a}$ & $0.79 \pm 0.07^{a}$ & $152.9 \pm 15.1^{\mathrm{a}}$ & $154.1 \pm 5.1^{\mathrm{a}}$ \\
\hline Damage & $3.01 \pm 0.08^{b}$ & $2.45 \pm 0.07^{b}$ & $379.7 \pm 11.3^{b}$ & $289.2 \pm 11.2^{\mathrm{b}}$ \\
\hline $0.05 \mathrm{mM}$ & $1.94 \pm 0.08^{c}$ & $1.60 \pm 0.07^{c}$ & $362.9 \pm 1.3^{b}$ & $243.0 \pm 7.2^{c}$ \\
\hline $0.10 \mathrm{mM}$ & $1.52 \pm 0.02^{d}$ & $1.18 \pm 0.04^{d}$ & $338.5 \pm 2.4^{c}$ & $220.4 \pm 12.7^{d}$ \\
\hline $0.15 \mathrm{mM}$ & $1.34 \pm 0.01^{\mathrm{e}}$ & $0.90 \pm 0.02^{\mathrm{a}}$ & $321.4 \pm 12.4^{\mathrm{a}}$ & $208.8 \pm 7.4^{d}$ \\
\hline $0.20 \mathrm{mM}$ & $1.11 \pm 0.00^{\mathrm{e}}$ & $0.88 \pm 0.07^{\mathrm{a}}$ & $229.6 \pm 20.1^{\mathrm{a}}$ & $180.3 \pm 17.9^{e}$ \\
\hline
\end{tabular}

Values are expressed as mean \pm SE. Dissimilar alphabets in superscript indicate significant difference at $p<0.05$. 
Table 3 Inhibition of protein oxidation by PTS was measured in terms of nmoles of protein carbonyls/mg protein and nmoles of protein sulphydryls/mg protein in TBHP and $\mathrm{As}-\mathrm{Fe}^{2+}$ mediated oxidatively damaged rat liver mitochondria

\begin{tabular}{|c|c|c|c|c|}
\hline & \multicolumn{2}{|c|}{$\begin{array}{l}\text { Protein carbonyl groups (nmoles protein } \\
\text { carbonyls/mg protein) }\end{array}$} & \multicolumn{2}{|c|}{$\begin{array}{l}\text { Protein sulphydryl groups (nmoles protein } \\
\text { sulphydryls/mg protein) }\end{array}$} \\
\hline & TBHP & As- $\mathrm{Fe}^{2+}$ & TBHP & As- $\mathrm{Fe}^{2+}$ \\
\hline Control & $3.54 \pm 0.02^{\mathrm{a}}$ & $3.78 \pm 0.21^{a}$ & $0.16 \pm 0.00^{\mathrm{a}}$ & $1.18 \pm 0.04^{a}$ \\
\hline Damage & $5.73 \pm 0.14^{b}$ & $5.87 \pm 0.02^{b}$ & $0.12 \pm 0.01^{b}$ & $0.91 \pm 0.01^{b}$ \\
\hline $0.05 \mathrm{mM}$ & $4.40 \pm 0.14^{c}$ & $5.35 \pm 0.26^{c}$ & $0.13 \pm 0.01^{c}$ & $1.02 \pm 0.03^{c}$ \\
\hline $0.10 \mathrm{mM}$ & $4.02 \pm 0.23^{d}$ & $4.73 \pm 0.02^{d}$ & $0.14 \pm 0.01^{c}$ & $1.04 \pm 0.01^{c}$ \\
\hline $0.15 \mathrm{mM}$ & $3.57 \pm 0.23^{\mathrm{a}}$ & $4.45 \pm 0.21^{d}$ & $0.14 \pm 0.01^{d}$ & $1.07 \pm 0.01^{d}$ \\
\hline $0.20 \mathrm{mM}$ & $3.55 \pm 0.01^{\mathrm{a}}$ & $3.92 \pm 0.16^{\mathrm{a}}$ & $0.15 \pm 0.00^{\mathrm{a}}$ & $1.15 \pm 0.01^{\mathrm{a}}$ \\
\hline
\end{tabular}

Values are expressed as mean \pm SE. Dissimilar alphabets in superscript indicate significant difference at $p<0.05$.

activity and also protected liver cells against ethanol induced oxidative stress [39]. Since Pterostilbene is one of the major active constituents in Pterocarpus marsupium, we speculated that Pterostilbene could have contributed to its anti-oxidant activity. Therefore, commercially available and purified Pterostilbene was studied with respect to its anti-oxidant activity. Earlier studies have reported anti-oxidant activity in terms of ability to scavenge DPPH and ABTS radicals; however, in this study we have evaluated comprehensively its anti-oxidant activity against a variety of free radicals. In addition to this, we have also assessed its ability to protect cellular biomolecules against oxidative damage. The results obtained indicate that Pterostilbene possesses strong anti-oxidant activity. Ability to scavenge and/or inhibit formation of free radicals was assessed by performing different in vitro radical scavenging assays. The DPPH• radical scavenging assay corresponds to the primary radical scavenging activity of an anti-oxidant, whereas ferrylmyoglobin/ABTS ${ }^{\cdot+}$ corresponds to the ability of an anti-oxidant to inhibit radical formation. Pterostilbene demonstrated ability to scavenge DPPH and inhibit ABTS radical formation in a concentration dependent manner which could be attributed to the ability of Pterostilbene to act as a donor of hydrogen atoms or electrons. Both, DPPH and ABTS radical scavenging activity of Pterostilbene is in accordance with the previous study [2,20]. The FRAP assay evaluates the reducing capacity of an anti-oxidant and Pterostilbene exhibited concentration dependent anti-oxidant potential. In biological systems, superoxide radicals are generated as a by-product of cellular respiration. Superoxide can generate hydroxyl radical by Haber Wiess reaction and produce $\mathrm{H}_{2} \mathrm{O}_{2}$ on dismutation by superoxide dismutase. Hydrogen peroxide is another biological reactive oxygen species, which at low concentration is necessary for cellular signaling, but at a high concentration it could be detrimental [40]. Under physiological conditions $\mathrm{H}_{2} \mathrm{O}_{2}$ is further decomposed into water and oxygen by catalase.
However, during stress conditions excess production of free radicals overwhelms the anti-oxidant defense system. This necessitates supplementation with antioxidants to maintain redox homeostasis. In the present study, Pterostilbene exhibited ability to scavenge superoxide, hydroxyl and $\mathrm{H}_{2} \mathrm{O}_{2}$ in a concentration dependent manner with maximum activity at $0.02 \mathrm{mM}(50 \mu \mathrm{g} / \mathrm{ml})$. Recent reports suggest that in humans Pterostilbene upto a dose of $250 \mathrm{mg} /$ day does not have any adverse toxic effects on hepatic and renal functions, thereby emphasizing its importance as a safe drug [41].

Free radicals generated in vivo as a result of cellular respiration have a very short half-life and the clearance rate of these radicals is very rapid. Taking this into consideration, pulse radiolysis was carried out to study reactions occurring on a time scale faster than one hundred microseconds and to study the kinetics of radical scavenging reactions. Pterostilbene exhibited $\mathrm{ABTS}^{+}, \mathrm{CO}_{3}{ }^{-}$ and $\cdot \mathrm{OH}$ radical scavenging activity in pulse radiolysis study indicating its ability to react with radicals within a short span of time, as needed in biological systems.

Table 4 Inhibition of DNA oxidation by PTS was measured in terms of nmoles 8-OHdG/100 ng DNA in TBHP and As- $\mathrm{Fe}^{2+}$ mediated oxidatively damaged rat liver mitochondria

\begin{tabular}{lll}
\hline & \multicolumn{2}{c}{ nmoles 8-OHdG/100 ng DNA } \\
\cline { 2 - 3 } & TBHP & As-Fe $^{2+}$ \\
\hline Control & $0.003 \pm 7.2 \mathrm{E}-05^{\mathrm{a}}$ & $0.003 \pm 7.6 \mathrm{E}-05^{\mathrm{a}}$ \\
Damage & $0.014 \pm 1.0 \mathrm{E}-04^{\mathrm{b}}$ & $0.013 \pm 4.2 \mathrm{E}-05^{\mathrm{b}}$ \\
$\mathbf{0 . 0 5} \mathbf{~ m M}$ & $0.007 \pm 1.0 \mathrm{E}-03^{\mathrm{c}}$ & $0.006 \pm 7.9 \mathrm{E}-05^{\mathrm{c}}$ \\
$\mathbf{0 . 1 0} \mathbf{~ m M}$ & $0.006 \pm 9.9 \mathrm{E}-04^{\mathrm{d}}$ & $0.006 \pm 2.5 \mathrm{E}-06^{\mathrm{c}}$ \\
$\mathbf{0 . 1 5} \mathbf{~ m M}$ & $0.005 \pm 7.7 \mathrm{E}-04^{\mathrm{e}}$ & $0.004 \pm 1.1 \mathrm{E}-04^{\mathrm{d}}$ \\
$\mathbf{0 . 2 0} \mathbf{~ \mathbf { ~ M }}$ & $0.003 \pm 4.5 \mathrm{E}-04^{\mathrm{a}}$ & $0.003 \pm 7.9 \mathrm{E}-04^{\mathrm{a}}$ \\
\hline
\end{tabular}

Values are expressed as mean \pm SE. Dissimilar alphabets in superscript indicate significant difference at $\mathrm{p}<0.05$. 


\section{A}

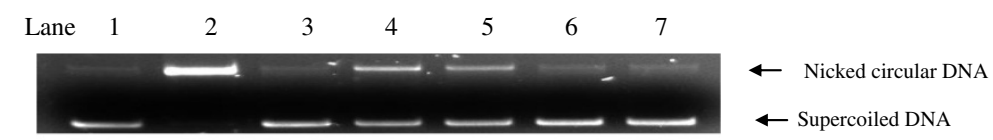

B

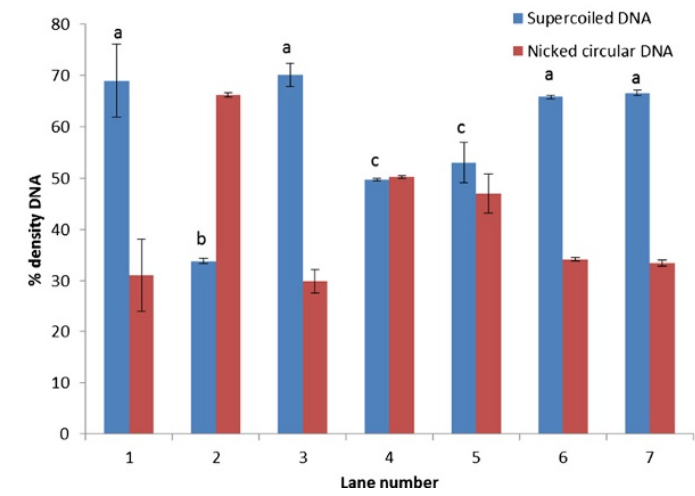

Figure 3 A. Gel electrophoresis pattern of pBR322 plasmid DNA after induction of oxidative damage in the presence of different concentrations of Pterostilbene. Lane 1-Undamaged DNA; Lane 2- Damaged DNA in presence of hydroxyl radical; Lane 3-DNA in presence of Pterostilbene alone; Lanes 4-7- oxidatively damaged DNA in presence of $0.05,0.10,0.15$ and $0.20 \mathrm{mM}$ Pterostilbene, respectively. B. Densitogram analysis of electrophoreogram to quantitate supercoiled and nicked circular DNA. Values are expressed as mean \pm SE. Dissimilar alphabets in superscript indicate significant difference at $p<0.05$.

Further, since mitochondria is a major sub-cellular organelle where the cellular system of energy provision is localised, rat liver mitochondria was used as a model system to study protective effect of Pterostilbene against $\mathrm{TBHP}$ and $\bullet \mathrm{OH}$ like radical (generated by Fenton reaction) induced oxidative damage. ROS exposure leads to a reduction in mitochondrial membrane potential, oxidation of functionally important thiol groups on mitochondrial enzymes and induces cell death $[42,43]$. ROS degrades polyunsaturated fatty acids, incorporated in all biological membranes, to peroxyl radicals (ROO) which is further converted to malondialdehyde (MDA) through a series of chain reactions. Damage to proteins is also of particular importance in vivo as it affects the functionality of several receptors, enzymes, transport proteins and contributes to secondary damage of other bio-molecules, e.g. by inactivating anti-oxidant defense enzymes or repair enzymes. ROS, especially hydroxyl radical is known to react with all the components of DNA, damaging both purine and pyrimidine bases and also the deoxyribose backbone [44] generating a wide range of oxidative DNA lesions, for example, 8-OHdG. This damage to bio-molecules within a cell results due to excessive ROS generation which overwhelms the intracellular defense mechanism. Therefore, dietary anti-oxidants capable of scavenging free radicals can prove to be beneficial in ameliorating these deleterious effects of ROS. Treatment with Pterostilbene, which in our study exhibited in vitro radical scavenging/inhibiting activity, also protected lipids, proteins and DNA in rat liver mitochondria from oxidative damage.

Additionally, ability of Pterostilbene to inhibit single strand DNA breaks was estimated using pBR322 DNA. Single strand breaks were induced by generating hydroxyl radical (by Fenton reaction) which converts the supercoiled DNA to nicked circular DNA. This damage was prevented in presence of different concentrations of Pterostilbene. This could be attributed to the fact that Pterostilbene scavenges hydroxyl radicals, as seen in this study, thereby protecting DNA against free radical assault. Additionally, polyphenols are also known as metal chelators and chelation of transition metals such as $\mathrm{Fe}^{2+}$ can directly reduce the rate of Fenton reaction, thereby protecting against damage by hydroxyl radicals [44].

Thus, the data obtained clearly shows that Pterostilbene has radical scavenging/inhibiting activity and also protects lipids, proteins and DNA against oxidative assault. Presence of a free 4-OH group in Pterostilbene is suggested to be crucial for its anti-oxidant activity [21].

\section{Conclusion}

The results obtained suggest that Pterostilbene, an ana$\log$ of Resveratrol, possesses strong free radical scavenging/inhibiting activity and also has the ability to protect bio-molecules in a cell against oxidative stress, thus potentiating its therapeutic role as an anti-oxidant. 


\section{Competing interest}

The authors declare that they have no competing interests.

\section{Authors' contributions}

JDA carried out all the experimental work, analysed the data and wrote the first draft. SSG supervised the study design and revised the manuscript. All authors read and approved the final manuscript.

\section{Acknowledgements}

The authors acknowledge financial support from DBT, DST-FIST and UGCCAS of Department of Zoology. JDA is a recipient of JRF under UGC-CAS program of Department of Zoology, University of Pune.

Received: 9 April 2013 Accepted: 24 September 2013

Published: 26 September 2013

\section{References}

1. Fremont L: Biological effects of resveratrol. Life Sci 2000, 66:663-673.

2. Rimando AM, Cuendet M, Desmarchelier C, Mehta RG, Pezzuto JM, Duke SO: Cancer chemopreventive and antioxidant activities of Pterostilbene, a naturally occurring analogue of resveratrol. J Agric Food Chem 2002, 50:3453-3457

3. Sehadri R: Polyphenols of Pterocarpus and Dalbergia woods. Phytochemistry 1984, 11(3):881-898.

4. Maurya R, Ray AB, Duah FK, Slatkin DJ, Schiff PR Jr: Constituents of Pterocarpusmarsupium. J Nat Prod 1984, 47(1):179-181.

5. Langcake $P$, Cornford CA, Pryce RJ: Identification of Pterostilbene as a phytoalexin from Vitisvinifera leaves. Phytochemistry 1979, 18(6):1025-1027.

6. Pezet $R$, Pon V: Identification of Pterostilbene in grape berries of Vitisvinifera. Plant Physiol Biochem (Paris) 1988, 26:603-607.

7. Tiwari S, Shah P, Singh K: In vitro propagation of Pterocarpusmarsupium: An endangered medicinal tree. Ind J Biotechnol 2004, 3(3):422-425.

8. Chakravarthy BK, Gupta S, Gambhir SS, Gode KD: Pancreatic beta cell regeneration -a novel anti-diabetic mechanism of Pterocarpusmarsupium roxb. Indian J Pharm 1980, 12(2):123-127.

9. Rajasekharan S, Tuli SN: Vijayasar, Pterocarpusmarsupium, in the treatment of Madhumeha (diabetes mellitus) - a clinical trial. J Res Ind Med Yoga Homeo 1976, 11:9-14.

10. ICMR study group: Efficacy of Vijayasar (Pterocarpusmarsupium) in the treatment of newly diagnosed patients with type 2 diabetes mellitus: a flexible dose double-blind multicentre randomised control study. Diabetol Croat 2005, 34(1):13-20.

11. Paul B, Masih I, Deopujari J, Charpentier C: Occurrence of resveratrol and Pterostilbene in age-old darakchasava, an ayurvedic medicine from India. J Ethnopharmacol 1999, 68(1-3):71-76.

12. Satheesh MA, Pari L: Effect of Pterostilbene on lipids and lipid profiles in streptozotocin-nicotinamide induced type 2 diabetes mellitus. J App Biomed 2008, 6:31-37.

13. Manickam M, Ramanathan M, Jahromi MA, Chansouria JP, Ray AB: Antihyperglycemic activity of phenolics from Pterocarpusmarsupium. J Nat Prod 1997, 60(6):609-610.

14. Pari L, Satheesh MA: Effect of Pterostilbene on hepatic key enzymes of glucose metabolism in streptozotocin and nicotinamide-induced diabetic rats. Life Sci 2006, 79(7):641-645.

15. Hougee S, Faber J, Sanders A, de Jong RB, van den Berg WB, Garssen J, Hoijer MA, Smit HF: Selective COX-2 inhibition by a Pterocarpusmarsupium extract characterized by Pterostilbene, and its activity in healthy human volunteers. Planta Med 2005, 71(5):387-392.

16. McCormack D, McFadden D: Pterostilbene and cancer: current review. J Surg Res 2012, 173(2):e53-e61.

17. Tsai ML, Lai CS, Chang YH, Chen WJ, Ho CT, Pan MH: Pterostilbene, a natural analogue of resveratrol, potently inhibits 7,12-dimethylbenz[a] anthracene(DMBA)/12-O-tetradecanoylphorbol-13-acetate (TPA)-induced mouse skin carcinogenesis. Food Funct 2012, 3(11):1185-1194.

18. Paul S, Rimando AM, Lee HJ, Ji Y, Reddy BS, Suh N: Anti-inflammatory action of Pterostilbene is mediated through the p38 mitogen-activated protein kinase pathway in colon cancer cells. Cancer Prev Res 2009, 2(7):650-657.

19. Rimando AM, Nagmani R, Feller DR, Yokoyama W: Pterostilbene, a new agonist for the peroxisome proliferator-activated receptor alpha-isoform, lowers plasma lipoproteins and cholesterol in hypercholesterolemic hamsters. J Agric Food Chem 2005, 53(9):3403-3407.

20. Remsberg CM, Yáñez JA, Ohgami Y, Vega-Villa KR, Rimando AM, Davies NM: Pharmacometrics of Pterostilbene: preclinical pharmacokinetics and metabolism, anticancer, anti-inflammatory, antioxidant and analgesic activity. Phytother Res 2008, 22(2):169-179.

21. Stivala LA, Savio M, Carafoli F, Perucca P, Bianchi L, Maga G, Forti L, Pagnoni UM, Albini A, Prosperi E, Vannini V: Specific structural determinants are responsible for the antioxidant activity and the cell cycle effects of resveratrol. J Biol Chem 2001, 276:22586-22594.

22. Aquino R, Morelli S, Lauro MR, Abdo S, Saija A, Tomaino A: Phenolic constituents and antioxidant activity of an extract of Anthuriumversicolor leaves. J Natl Prod 2001, 64:1019-1023.

23. Pulido R, Bravo L, Saura-Calixto F: Antioxidant activity of dietarypolyphenols as determined by a modified Ferric Reducing Antioxidant Power assay. J Agric Food Chem 2000, 46:3396-3402.

24. Alzoreky N, Nakahara K: Antioxidant activity of some edible Yemeni plants evaluated by Ferrylmyoglobin/ABTS.+ ${ }^{+}$assay. Food Sci Technol Res 2001, 7:141-144.

25. Halliwell B, Gutteridge JMC, Aruoma Ol: Deoxyribose method: a simple "test-tube assay" for determination of rate constants for reaction of hydroxyl radical. Anal Biochem 1987, 165:215-219.

26. Nabavi SM, Ebrahimzadeh MA, Nabavi SF, Jafari M: Free radical scavenging activity and antioxidant capacity of Eryngium Caucasium Trautv and Froriepia subpinnata. Pharmacologyonline 2008, 3:19-25.

27. Ukeda H, Kawana D, Maeda S, Sawamura M: Spectrophotometric assay for superoxide dismutase based on the reduction of highly water-soluble tetrazolium salts by xanthine-xanthine oxidase. Biosci Biotechnol Biochem 1999, 63:485-488.

28. Dixit PP, Ghaskadbi SS, Mohan H, Devasagayam TPA: Antioxidant properties of germinated fenugreek seeds. Phytother Res 2005, 19:977-983.

29. Naik GH, Priyadarsini Kl, Hari M: Free radical scavenging reaction and phytochemical analysis of triphala, an ayurvedic formulation. Curr Sci 2006, 90:1100-1105.

30. Londhe JS, Devasagayam TPA, Foo LY, Ghaskadbi SS: Antioxidant activity of some polyphenol constituents of the medicinal plant Phyllanthusamarus Linn. Redox report 2008, 13(5):199-207.

31. Devasagayam TPA: Lipid peroxidation in rat uterus. Biochimica Biophysica Acta 1986, 876:507-514.

32. Lowry OH, Rosebrough NJ, Farr AL, Randall RJ: Protein measurement with folin phenol reagent. J Biol Chem 1951, 193:265-275.

33. Devasagayam TPA, Pushpendran CK, Eapen J: Difference in lipid peroxidation in rat liver rough and smooth microsomes. Biochem Biophys Acta 1983, 750:91-97.

34. Dalle-Donne I, Rossi R, Giustarini D, Milzani A, Colombo R: Protein carbonyl groups as biomarkers of oxidative stress. Clin Chim Acta 2003, 29:23-38

35. Ellmann GL: Tissue sulphydryl groups. Arch Biochem Biophys 1959, $82: 70-77$

36. Nourooz-Zadeh J, Jajaddini-Sarmadi J, Ling KL, Wolff SP: Low density lipoprotein is the major carrier of lipid hydroperoxides in plasma. Relevance to determination of total plasma lipid hydroperoxide concentrations. Biochem J 1996, 313:781-786.

37. Modak MA, Parab PB, Ghaskadbi SS: Pancreatic islets are very poor in rectifying oxidative DNA damage. Pancreas 2010, 38:23-29.

38. Zhao C, Dodin G, Yuan C, Chen H, Zheng R, Jia Z, Fana Bo-Tao T: In vitro protection of DNA from Fenton reaction by plant polyphenol verbascoside. Biochimica Biophysica Acta 2005, 1723:114-123.

39. Mohammadi M, Khole S, Devasagayam TPA, Ghaskadbi SS: Pterocarpusmarsupium extract reveals strong in vitro antioxidant activity. Drug Discov Ther 2009, 3(4):151-161.

40. Pi J, Zhang Q, Fu J, Woods CG, Hou Y, Corkey BE, Collins S, Andersen ME: Reactive oxygen species as a signal in glucose-stimulated insulin secretion. Toxicol Appl Pharmacol 2010, 244(1):77-83.

41. Masaki N, Kyle ME, Serroni A, Farber JL: Mitochondrial damage as a mechanism of cell injury in the killing of cultured hepatocytes by tertbutyl hydroperoxide. Arch Biochem Biophys 1989, 270:672-680.

42. Bhattacharya S, Manna P, Gachhui R, Sil PC: Protective effect of Kombucha tea against tertiary butyl hydroperoxide induced 
cytotoxicity and cell death in murine hepatocytes. Indian Journal of Exp Biol 2011, 49:511-524.

43. Halliwell B, Gutteridge JMC: Free radicals in biology and medicine. Thirdth edition. Oxford, UK: Oxford University Press; 1999.

44. Perron NR, Brumaghim JL: A review of the antioxidant mechanisms of polyphenol compounds related to iron binding. Cell Biochem Biophys 2009, 53:75-100.

doi:10.1186/1472-6882-13-238

Cite this article as: Acharya and Ghaskadbi: Protective effect of

Pterostilbene against free radical mediated oxidative damage. BMC

Complementary and Alternative Medicine 2013 13:238.

\section{Submit your next manuscript to BioMed Central and take full advantage of:}

- Convenient online submission

- Thorough peer review

- No space constraints or color figure charges

- Immediate publication on acceptance

- Inclusion in PubMed, CAS, Scopus and Google Scholar

- Research which is freely available for redistribution 